\title{
Pemanfaatan Media Sosial Oleh Komunitas Historia Indonesia
}

\author{
Natasha Angela, M Gafar Yoedtadi \\ natashaangelaa18@gmail.com,gafary@fikom.untar.ac.id
}

Fakultas Ilmu Komunikasi Universitas Tarumanagara

\begin{abstract}
Internet has become necessary for everyone in the current era of information technology. Technology allows millennial to be exposed to foreign cultures which are adapted to their current social life. This could be one of the reason that young generation do not have interest to explore traditional culture and history of Indonesia. By utilizing mass media, various historical communities have emerged as a place for people who care to preserve Indonesia's historical and cultural heritage. This research examine social media usage by Indonesia Historia Community (KHI) in enhancing the nationalism of young generation. The theory used are New Media, Social Media, Cyber Public Relations, and Social Media Marketing. The research was conducted by case study method through depth interview and participant observation. The result shows that KHI utilize social media as a means of information, recruitment, education, interaction and communication, and creating differentiation as a strategy taken by KHI to reach public and teach history in fun and entertaining approach. KHI also carries out social media marketing technique to create space for those who wants to cultivate their interest and shape a history lover lifestyle, so it hoped that KHI will has a strong identity as Indonesia's largest history community.
\end{abstract}

Keywords: cyber public relations, social media, social media marketing

\begin{abstract}
Abstrak
Internet telah menjadi kebutuhan masyarakat di seluruh dunia pada zaman teknologi informasi saat ini. Dalam kehidupan sosial, teknologi membuat generasi milenial diperkenalkan pada budaya dan gaya hidup luar yang kemudian diadaptasi dalam kehidupan terkini. Hal ini yang membuat generasi muda saat ini tidak memiliki perhatian dan ketertarikan untuk mendalami budaya tradisional dan sejarah Indonesia. Dengan memanfaatkan media massa, muncul berbagai komunitas sejarah sebagai wadah bagi masyarakat yang masih peduli dan ingin bersama menjaga warisan sejarah dan budaya Indonesia. Sehingga penelitian ini dimaksudkan untuk meneliti pemanfaatan media sosial oleh Komunitas Historia Indonesia (KHI) dalam meningkatkan nasionalisme generasi muda. Penelitian berlandaskan teori New Media, Media Sosial, Cyber Public Relations, dan Social Media Marketing. Penelitian menggunakan pendekatan kualitatif dengan metode studi kasus. Hasil penelitian menunjukkan bahwa dalam melaksanakan kegiatannya, KHI memanfaatkan media sosial sebagai sarana informasi, rekrutmen, edukasi, interaksi dan komunikasi, dan menciptakan diferensiasi sebagai strategi yang dilakukan KHI untuk menjadi pengajar sejarah dan budaya dan menjangkau publik yang memiliki minat dan misi yang sama untuk melestarikan sejarah. KHI juga melakukan teknik social media marketing untuk menciptakan ruang bagi publik dalam mengolah minat dan membentuk gaya hidup yang cinta sejarah, sehingga diharapkan KHI semakin memperkuat identitasnya sebagai komunitas sejarah terbesar di Indonesia.
\end{abstract}

Kata Kunci: cyber public relations, media sosial, social media marketing 


\section{Pendahuluan}

Internet telah menjadi kebutuhan masyarakat di seluruh dunia pada zaman teknologi informasi saat ini. Kehidupan manusia tidak lekang dari keberadaan digital media (new media) dalam bentuk perangkat digital seperti mobile phone yang memudahkan manusia mencari informasi, saling berinteraksi, bersosialisasi, dan melakukan aktivitas bisnis (Irfan, 2014). Dalam proses komunikasi, diperlukan media sebagai saluran penyampaian pesan (Azeharie dan Kusuma, 2014) terutama dalam kegiatan komunikasi massa yang mempengaruhi hubungan dan kegiatan manusia. Perkembangan teknologi internet diiringi pula dengan pertumbuhan media sosial yang semakin pesat, sehingga memudahkan para pengguna untuk saling berkomunikasi (Azeharie dan Kusuma, 2014). Dilansir katadata.co.id, hasil riset pada Januari 2019 menunjukkan pengguna media sosial di Indonesia mencapai 150 juta atau $56 \%$ dari total populasi.

Penemuan diatas menunjukkan bahwa masyarakat Indonesia telah 'melek teknologi'. Teknologi membuat milenial dapat mengandalkan media sosial sebagai tempat mendapatkan informasi, platform pelaporan, dan sumber utama berita, serta diperkenalkan pada budaya dan gaya hidup luar, yang kemudian diadaptasi dalam kehidupan terkini yang sarat akan modernitas. Modernisasi pada dasarnya beranggapan bahwa keterbelakangan yang membelenggu masyarakat dunia ketiga, bersumber dari masyarakat itu sendiri, yaitu mentalitas individu dan kebudayaan tradisional (Arifin, 2011).

Dilansir dari cnnindonesia.com, museum di Indonesia masih digambarkan sebagai kuno dan menjenuhkan oleh masyarakat. Banyak generasi muda yang lebih tertarik belajar budaya asing dibandingkan mengenal lebih dalam budaya bangsa sendiri. Hal ini menunjukkan generasi muda saat ini tidak memiliki perhatian dan ketertarikan untuk mendalami budaya tradisional dan sejarah Indonesia, karena kurangnya semangat nasionalisme. Menurut Sarman dalam Kusumawardani dan Faturochman (2004) nasionalisme sering diartikan sebagai kecintaan terhadap tanah air yang tanpa pamrih dan merupakan simbol patriotisme heroik semata sebagai bentuk perjuangan demi negara yang dicintai.

Kondisi ini mendorong munculnya berbagai komunitas sejarah dan budaya yang mampu menjadi wadah bagi masyarakat yang masih peduli dan ingin bersama menjaga warisan sejarah dan budaya Indonesia. Salah satu organisasi yang mempelopori ini adalah Komunitas Historia Indonesia (KHI). Resmi berdiri pada 22 Maret 2003, tujuan berdirinya Komunitas Historia Indonesia adalah menjadi edukator sejarah dan budaya dengan cara yang menyenangkan dalam rangka membangun semangat nasionalisme dalam masyarakat. Dengan pemahaman lebih dalam penggunaan media baru, maka KHI memanfaatkan media sosial sebagai medium komunikasi untuk meraih target khalayak yang sesuai yaitu generasi muda.

McQuail (2011) menjelaskan bahwa new media (media baru) adalah berbagai perangkat teknologi komunikasi yang berbagi ciri yang sama yaitu digitalisasi dan ketersediaan luas untuk digunakan sebagai alat komunikasi pribadi. Yanuar Luqman (2014) menjelaskan internet telah menambahkan suatu dimensi baru bagi dunia kehumasan. Ia membuka saluran komunikasi baru antara korporat dan publik, juga antara praktisi kehumasan dan media.

Dalam perkembangannya, internet menghasilkan medium interaksi baru yaitu media sosial, yang merupakan teknologi berbasis website yang dapat membentuk jaringan, serta memungkinkan orang untuk berinteraksi dalam sebuah komunitas 
(Puntoadi, 2011). Menurut Nasrullah (2016) media sosial merupakan medium di internet yang memungkinkan penggunanya mempresentasikan dirinya maupun berinteraksi, bekerja sama, saling berbagi, berkomunikasi dengan pengguna lainnya, dan membentuk ikatan sosial secara virtual. Pengertian ini ditegaskan oleh Van Dijk dalam Nasrullah (2016) yang mengatakan media sosial sebagai platform media yang fokus pada eksistensi pengguna yang memfasilitasi mereka dalam beraktivitas maupun berkolaborasi.

Puntoadi (2011) menjelaskan dalam media sosial kita dapat melakukan aktivitas dua arah dalam berbagai bentuk pertukaran, kolaborasi, dan saling berkenalan dalam bentuk tulisan, visual, maupun audio visual. Hal-hal seperti itulah yang secara nyata tidak ditemukan pada media berbasis web 1.0. Dalam Safko (2010) alasan media sosial menjadi jauh lebih efektif dibandingkan teknik marketing konvensional adalah komunikasi dua arah. Konsumen tidak lagi percaya pada pesan komersial, sebaliknya mereka ingin mendapatkan informasi dari pengalaman orang lain yang dibagikan. Hal ini sejalan dengan pendapat Looy (2016) bahwa faktor utama suksesnya publikasi di media sosial yaitu konten, karena semakin relevan konten tersebut dengan publik, maka akan semakin besar kemungkinan orang akan membagikannya ke orang terdekat yang dikenal, sehingga mendorong business outcomes (kenaikan penjualan, loyalitas konsumen, menarik konsumen baru, membangun brand image, dan lainnya). Menurut Puntoadi (2011) menciptakan diferensiasi adalah kunci utama untuk mendapatkan popularitas di media sosial.

Social Media Marketing merepresentasikan kondisi bisnis saat ini dimana membutuhkan alat promosi dengan biaya minim, digabungkan dengan teknologi dan interaksi sosial untuk membawa keuntungan bagi perusahaan, dan alat yang paling tepat digunakan adalah media sosial (Neti, 2011). Dalam Evans (2010) Social Media Marketing memungkinkan pelaku bisnis untuk membangun bisnis secara sosial, artinya ada proses partisipatif dan kolaboratif antara perusahaan dan konsumen, dengan melibatkan mereka dalam desain dan operasional perusahaan yang terasosiasi dengan minat mereka. Komunitas yang kuat adalah yang mampu membangun hal-hal yang dianggap penting bagi anggota komunitas, yaitu passion, gaya hidup (lifestyle), dan kebutuhan selaras lainnya (Evans, 2010).

Berdasarkan pemikiran diatas, permasalahan yang diangkat dalam penelitian ini adalah bagaimana strategi pemanfaatan media sosial oleh Komunitas Historia Indonesia untuk meningkatkan nasionalisme generasi muda.

\section{Metode Penelitian}

Dalam penelitian ini menggunakan pendekatan kualitatif yang pada dasarnya merupakan cara ilmiah untuk mendapatkan data dengan tujuan memahami, memecahkan, dan mengantisipasi masalah. Metode penelitian yang digunakan adalah studi kasus. Teknik pengumpulan data dilakukan dengan observasi, wawancara, dan dokumentasi. Tujuannya untuk melakukan pengumpulan data secara intensif, mencatat secara hati-hati apa yang terjadi, dan melakukan analisis reflektif terhadap temuan yang diperoleh mengenai pemanfaatan media sosial oleh KHI. Teknik analisis data berupa pengumpulan data, reduksi data, penyajian data, dan penarikan kesimpulan. Pemeriksaan keabsahan data dilakukan dengan induksi analitik yaitu menguji temuan di lapangan dengan indeks internal dan contoh-contoh dari sumber yang berbeda, dalam hal ini kajian teoritis. 
Subjek penelitian ini adalah Asep Kambali, selaku Pendiri dan Ketua Komunitas Historia Indonesia. Objek penelitian adalah Komunitas Historia Indonesia yang merupakan komunitas sejarah terbesar di Indonesia, dan memiliki akun media sosial aktif untuk melakukan publikasi. Sehingga, data primer diperoleh wawancara mendalam dengan Asep Kambali dan observasi partisipan terhadap acara yang diselenggarakan oleh KHI. Data sekunder diperoleh melalui sumber buku, jurnal ilmiah, dan artikel online yang relevan dengan topik penelitian.

\section{Hasil Temuan dan Diskusi}

\section{Latar Belakang Pemanfaatan Media Sosial Oleh KHI}

Komunitas yang awalnya berdiri atas dasar kesamaan minat dan latar belakang para pengurusnya, di kemudian hari mulai muncul keinginan untuk mengenalkan komunitas ini kepada masyarakat luas, sehingga tidak hanya pengurusnya yang terlibat dalam melestarikan sejarah Indonesia, tetapi masyarakat juga turut berpartisipasi. Penting untuk menyadari bahwa perlu ada pendekatan khusus untuk mengenalkan sejarah bagi generasi muda, terutama karena mereka identik dengan minat besar bermain media sosial ketimbang membaca buku sejarah. Target khalayak KHI adalah dewasa muda usia 25-34, kemudian remaja 18-24 tahun yang setara dengan tujuan utama pemanfaatan media sosial KHI yaitu merangkul generasi muda untuk belajar mencintai dan melestarikan sejarah.

Menurut Kang Asep selaku Ketua KHI, perlu ada trik dan strategi untuk mengenalkan sejarah kepada generasi muda, yang tentunya harus menggunakan alatalat yang memang sesuai dengan zaman sekarang, salah satunya adalah media sosial. Maka, KHI bertekad untuk rajin mengunggah konten-konten sejarah di Instagram yang sifatnya informatif atau menghibur tapi edukatif (memuat pesan-pesan sejarah). Titik dimana KHI mulai beralih memanfaatkan media sosial diakui Kang Asep sebagai cara agar KHI turut berkembang mengikuti zaman.

\section{Jenis-Jenis Media Sosial KHI: Website}

Website KHI didesain secara sederhana untuk memudahkan navigasi publik ketika ingin mencari informasi yang diinginkan seperti sejarah organisasi, susunan kepengurusan, program komunitas, informasi keanggotaan dan kerja sama, hingga penghargaan dan prestasi yang dicapai KHI sehingga mendapatkan kredibilitas sebagai komunitas pecinta sejarah terbesar di Indonesia. Secara keseluruhan, website KHI menyajikan informasi yang sangat lengkap dengan memanfaatkan kelebihan website yang dapat memuat berbagai format tulisan, gambar, dan video.

\section{Instagram}

Dianggap memiliki efek paling besar, kini Instagram aktif digunakan untuk promosi dan publikasi KHI. KHI memiliki pengikut sebanyak 15.800 orang, dengan jumlah pengikut potensial yang aktif mencapai lebih dari $50 \%$ atau 8.000 orang. KHI mencantumkan secara jelas identitas dan profil organisasinya di kolom biografi. Konten yang ada di Instagram KHI sebagian besar berisi informasi berita sejarah, galeri foto, serta informasi lain mengenai kegiatan kesejarahan. Instagram KHI mendapatkan rata-rata 400 likes dan 20 komentar dalam setiap unggahan. 


\section{Facebook}

Facebook KHI kini diikuti oleh 12.676 orang. Konten yang diunggah tidak jauh berbeda dengan yang ada di Instagram, namun didominasi oleh galeri foto yang berisi foto-foto lengkap kegiatan KHI yang berjalan hingga saat ini. Publik yang masih aktif menggunakan Facebook dapat melihat seperti apa acara-acara yang diselenggarakan KHI, dan kedekatan interaksi antara KHI dengan anggota dan peserta acara. Data Facebook menunjukkan akun Facebook KHI rata-rata dikunjungi oleh 150 orang setiap harinya, dan keseluruhan posting mendapatkan 12.628 likes.

\section{Twitter}

Sama seperti Facebook, KHI juga mengoperasikan konten Twitter seperti konten yang diunggah di Instagram. Perbedaan hanya terletak pada dimensi gambar saja, karena Instagram, Facebook, dan Twitter mensyaratkan dimensi (ukuran) foto yang berbeda-beda agar foto tampak jernih ketika diunggah. Twitter KHI memiliki 13.600 pengikut dan total likes 1.123 . Salah satu cara untuk meningkatkan engagement publik Twitter adalah menyajikan gambar dalam setiap unggahan. Jika tidak ada foto yang diunggah, maka dapat menambahkan emoji pada teks yang ditulis agar bahasa unggahan terkesan lebih ramah dan dekat.

\section{Aplikasi}

KHI juga sedang dalam proses pembuatan aplikasi yang diberi nama Komunitas Historia. Menarik bahwa ketika membuka aplikasi ini, setiap pengguna akan dialihkan ke halaman berisi pesan sejarah sebelum masuk halaman utama. Melalui aplikasi Komunitas Historia, KHI ingin selangkah lebih dekat lagi dengan masyarakat, dengan mengeluarkan aplikasi yang lebih praktis dan mudah diakses dibanding website. Dalam aplikasi ini, masyarakat akan dengan mudah mendapat pemberitahuan tentang informasi berita sejarah dimana saja dan kapan saja.

\section{Fungsi Media Sosial Oleh KHI: Sumber Informasi}

Menurut Yanuar Luqman (2014) internet menjadi media komunikasi yang efektif karena berpotensi mengubah secara drastis banyak aspek sekaligus membuat pekerjaan menjadi lebih mudah. KHI memanfaatkan internet sebagai sumber informasi, yaitu memanfaatkan media sosial untuk mencari berita yang relevan dengan perkembangan komunitas, dan memberikan informasi tersebut kepada khalayak luas. Dengan media sosial, KHI dapat memantau tren apa yang sedang populer di masyarakat, dan dapat digunakan sebagai ide untuk mengembangkan acara KHI selanjutnya. KHI juga dapat terhubung dengan kanal berita untuk mendapatkan informasi seputar perkembangan sosial, pendidikan, sejarah, dan budaya di Indonesia dengan cepat, hal ini sesuai dengan fungsi media sosial sebagai medium bersosialisasi yang secara cepat menyebar informasi dan pengetahuan ke pengguna dalam jumlah banyak (Neti, 2011).

\section{Rekrutmen}

Media sosial menyediakan fitur berbasis website yang dapat membentuk jaringan serta memungkinkan orang untuk berinteraksi dalam sebuah komunitas (Puntoadi, 2011). Perlu ada medium bagi masyarakat yang memiliki minat dalam kesejarahan untuk berkumpul bersama dan berbagi pikiran, sehingga KHI memanfaatkan media sosial untuk membuka rekrutmen menjadi anggota KHI. Lewat 
media sosial, KHI dapat mempublikasikan berita rekrutmen dimana orang-orang yang tertarik untuk bergabung dan bersama memperjuangkan sejarah Indonesia. Persyaratan yang harus dipenuhi oleh calon anggota adalah berusia 15-30 tahun, pendidikan pelajar, mahasiswa, atau pekerja, memiliki kepribadian aktif, kreatif, imajinatif, berkomitmen, dan bertanggung jawab, dan yang utama adalah memiliki akun media sosial yang aktif.

\section{Edukasi}

Merujuk pada konsep web 2.0 yaitu penggunaan internet dalam rangka membuat konten, berbagi, dan berkolaborasi dengan sesama pengguna internet (Kaplan dan Haenlein dalam Looy (2016), KHI memanfaatkan media sosial untuk mengunggah konten pembelajaran mengenai sejarah dan budaya Indonesia. KHI memanfaatkan fitur-fitur unik yang disediakan media sosial, teknik desain foto, dan story-telling caption yang secara nyata tidak ditemukan pada media berbasis web 1.0 (Puntoadi, 2011). Kang Asep juga menambahkan bahwa konten-konten dari media sosial harus disesuaikan dengan karakteristik milenial yang serba instan. Dalam hal ini, sejarah tidak hanya disajikan secara tekstual tetapi harus disertakan dengan analogi (contoh) agar mudah dimengerti dan menarik. Dalam hal ini KHI meyakini pentingnya membuat visualisasi sejarah lewat foto atau video agar mempermudah menggambarkan peristiwa di benak seseorang. Sejalan dengan pendapat Luqman (2014) bahwa berbagai bentuk fasilitas teknologi internet seperti situs jejaring sosial dan blog memungkinkan individu dan komunitas masyarakat mempresentasikan atau menggambarkan diri dengan sebaik-baiknya.

\section{Sarana Interaksi dan Komunikasi}

Sesuai dengan pendapat Nasrullah (2016) bahwa media sosial merupakan medium di internet yang memungkinkan penggunanya mempresentasikan dirinya, berinteraksi, bekerja sama, saling berbagi, berkomunikasi dengan pengguna lainnya dan membentuk ikatan sosial secara virtual, maka media sosial KHI khususnya Instagram, membuka ruang agar para admin dapat berdiskusi secara terbuka dengan publik yang ingin memberikan informasi, pertanyaan, kritik, dan saran. Publik sangat terbuka untuk menyampaikan jika ada informasi sejarah yang ingin diketahui lebih lengkap, maka admin KHI akan menjawab bahkan berdiskusi lebih lanjut. Dengan cara ini, publik dapat ikut terlibat sebagai informan yang memberikan informasi yang diketahuinya sesuai fakta yang terverifikasi, sehingga tercapai fungsi Cyber Public Relations menurut Onggo (2004) yaitu membangun ribuan one-on-one relations secara simultan lewat interaktivitas media.

\section{Menciptakan Diferensiasi}

Menurut Puntoadi (2011) menciptakan diferensiasi adalah kunci utama mendapatkan popularitas di media sosial. Hashtag merek dapat menciptakan customer engagement dengan cara seorang pengguna merek tersebut memberikan pengalaman pada komunitas media sosial lainnya sehingga mereka mengetahui apa yang ingin diketahui tentang merek yang sedang tren dan bahkan mereka dapat mempromosikan merek tersebut (Simbolon, 2017). KHI menggunakan hashtags utama \#historiawarrior, \#komunitashistoria, \#indohistoria, \#sejarahindonesia, \#pejuang sejarah, dan bisa ditambahkan dengan hashtags lain sesuai keperluan posting. 


\section{Social Media Marketing}

Dengan teknik ini, KHI mengaplikasikan peran media sosial menurut Van Dijk dalam Nasrullah (2016) yang fokus pada eksistensi pengguna untuk memfasilitasi mereka dalam belajar, berbagi, dan berkolaborasi dalam sebuah kegiatan. Salah satu cara yang digunakan adalah peserta acara diminta mengunggah foto selama mengikuti acara di media sosial mereka, dan diberi hadiah berupa vouchers, barang, pulsa, tergantung ketersediaan saat acara.

Media sosial adalah tempat yang paling mudah untuk memulai interaksi antara partisipan yang sebelumnya tidak saling mengenal menjadi saling mengenal dan terlibat dalam kegiatan yang sama. Dengan bantuan media sosial, acara-acara yang diunggah dapat menarik perhatian mereka yang sebelumnya tidak tertarik, sehingga KHI sukses membentuk gaya hidup cinta sejarah di lingkup anggota komunitas yang kemudian dapat ditularkan kepada banyak orang. Hal ini sejalan dengan pendapat Evans (2010) bahwa komunitas yang kuat adalah yang mampu membangun hal-hal yang dianggap penting bagi anggota komunitas, yaitu minat, gaya hidup, dan kebutuhan selaras lainnya.

\section{Pengaruh Pemanfaatan Media Sosial Oleh KHI:}

Sejak aktif menggunakan media sosial, banyak perubahan yang dirasakan KHI. Sampai saat ini, KHI adalah pelopor komunitas sejarah yang terbesar di Indonesia. Berkat aktif di media sosial, KHI mendominasi SEO (Search Engine Optimization) dan mendapatkan peringkat teratas di pencarian dengan menggunakan kata kunci 'komunitas sejarah di Indonesia' dan sejenisnya.

KHI juga merasakan adanya penambahan pada jumlah peserta acara dan jumlah anggota baru yang bergabung dengan KHI. Jika melihat data insight Instagram KHI, setiap unggahan akan meraih impression baik dari 50\% pengikut (8.000 dari 15.000 pengikut) dengan minat terbesar di acara wisata malam. Sangat jauh berbeda dari sebelum KHI memanfaatkan media sosial, yang hanya meraih $10 \%$ jumlah peserta saja. Dari sisi keanggotaan, tahun 2003 KHI mulai beroperasi dengan 7 orang pengurus dan 650 relawan aktif. Kemudian semenjak KHI mengaktifkan media sosial di tahun 2008, berkembang menjadi 15 pengurus, 30 anggota aktif, dan 23.500 relawan muda dari berbagai kalangan. Penambahan jumlah anggota ini menunjukkan semakin banyak generasi muda yang dirangkul oleh KHI untuk turut menjadi relawan aktif dalam menjaga kelestarian sejarah dan budaya.

\section{Simpulan}

Komunitas Historia Indonesia (KHI) muncul sebagai pelopor komunitas sejarah dan budaya yang menjadi tempat berkumpulnya generasi muda dalam menyalurkan minat melestarikan sejarah Indonesia. Dalam kegiatannya, KHI memanfaatkan media sosial sebagai medium yang tepat untuk menjangkau generasi muda dengan melakukan fungsi sumber informasi, rekrutmen, edukasi, sarana interaksi dan komunikasi, serta menciptakan diferensiasi. Agar dapat menjadi wadah menciptakan lingkungan bisnis yang partisipatif dan kolaboratif, KHI juga menggunakan teknik social media marketing untuk memanfaatkan eksistensi pengguna dalam belajar, berbagi, dan berkolaborasi di kegiatan yang diikuti. Hasil dari pemanfaatan media sosial terlihat dari aspek internal berupa penambahan jumlah anggota dan peserta acara. KHI juga mendominasi SEO (Search Engine Optimization) untuk kata kunci komunitas sejarah dan sejenisnya sehingga memudahkan orang yang 
mencari informasi seputar KHI di mesin pencarian, serta mengukuhkan posisinya sebagai komunitas sejarah terbesar di Indonesia. Hal ini menunjukkan keaktifan KHI di media sosial telah terbukti mampu membawa perubahan internal dan eksternal komunitas kearah yang lebih positif. Agar dapat meningkatkan kualitas media sosialnya, KHI dapat menggunakan tenaga profesional seperti social media specialist untuk mengelola konten agar lebih terstruktur dan konsisten dalam menyajikan bahasan yang informatif, edukatif, sekaligus menghibur.

\section{Ucapan Terima Kasih}

Penulis menyampaikan terima kasih kepada Komunitas Historia Indonesia, terkhusus Kang Asep Kambali dan pengurus yang telah meluangkan waktu untuk bersedia diwawancarai dan menjawab pertanyaan selama observasi. Serta kepada seluruh pihak yang berkontribusi dalam penelitian ini sehingga dapat terwujud menjadi sebuah tulisan yang bermanfaat bagi kepentingan akademis dan praktisi komunikasi.

\section{Daftar Pustaka}

Azeharie, Suzy., \& Kusuma, Octavia. (2014). Analisis Penggunaan Twitter Sebagai Media Komunikasi Selebritis di Jakarta. Jurnal Komunikasi, 6, 2, 83-97. Terarsip

di: https://journal.untar.ac.id/index.php/komunikasi/article/view/35/17

Evans, Dave. (2010). Social Media Marketing. Indiana: Wiley Publishing. Terarsip di: https://www.pauladaunt.com/books/Social\%20Media\%20Marketing.pdf

Kusumawardani, Anggraeni \& Faturochman. (2004). Nasionalisme. Buletin Psiokologi Universitas Gadjah Mada, 2, 61-72. Terarsip di: https://jurnal.ugm.ac.id/buletinpsikologi/article/view/7469/5808

Looy, Amy Van. (2016). Social Media Management. Switzerland: Springer International.

McQuail, Denis. (2011). Teori Komunikasi Massa. Jakarta: Salemba Humanika.

Mulyana, Deddy., Arifin, Anwar., \& Cangara, Hafied. (2011). Ilmu Komunikasi: Sekarang dan Tantangan Masa Depan. Jakarta: Kencana.

Nasrullah, Rulli. (2016). Media Sosial: Perspektif Komunikasi, Budaya, dan Sosioteknologi. Bandung: Simbiosa Rekatama Media.

Neti, Sisira. (2011). Social Media And Its Role In Marketing. International Journal of Enterprise Computing and Business Systems,1, 2-8. Terarsip di: https://www.ijecbs.com/July2011/13.pdf

Puntoadi, Danis. (2011). Menciptakan Penjualan Melalui Social Media. Jakarta: PT Elex Media Komputindo.

Safko, Lon. (2010). The Social Media Bible Second Edition. New Jersey: John Wiley $\&$ Sons, Inc.

Simbolon, Freddy. (2017, Maret 8). Peran Hashtag Dalam Dunia Marketing. Desember 9, 2019. Binus Database. http://bbs.binus.ac.id/internationalmarketing/2017/03/peran-hastag-dalam-dunia-marketing/ 